Dept. of Virology,

Faculty of Veterinary Medicine,

Banha University, 13736 Moshtoher, Banha, Egypt.

\title{
ELECTRON, IMMUNO ELECTRON MICROSCOPY AND RT-PCR DETECTION, AND PATHOTYPING OF AVIAN PARAMYXOVIRUS TYPE 1 (NEWCASTLE DISEASE VIRUS) IN PIGEONS
}

(With One Table and 5 Figures)

\author{
By \\ S.S.A. SHARA WI; E.M. EL-NAHAS and A.S. EL-HABBAA \\ (Received at 15/9/2010)
}

الكثف المجهري والمناعي الإكتروني وطريقة النسخ العكسي الإستردادي

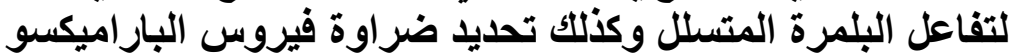

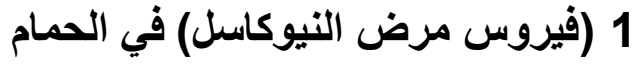

سعد شعراوي علحي شعراوي ، إيهاب مصطفى النحاس ، أيهن سعيل الهباء

نم جمع عدد 15 حمامة كعينة عشو ائية من سرب حمام يعاني من تفشي أعر اض عصبي عصبية من أحد

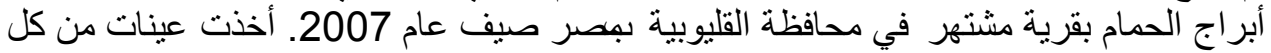

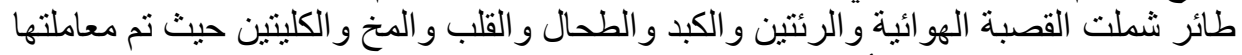

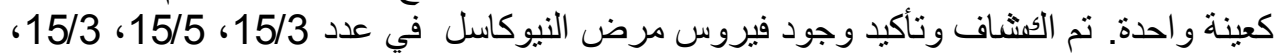

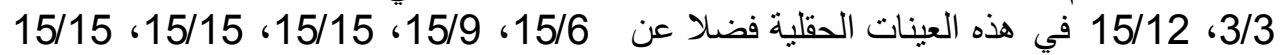

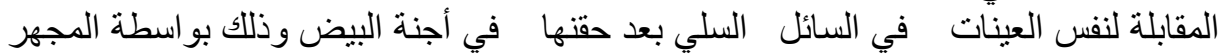

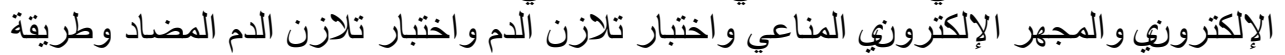

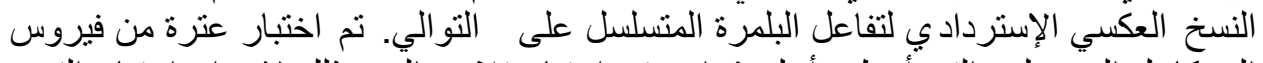

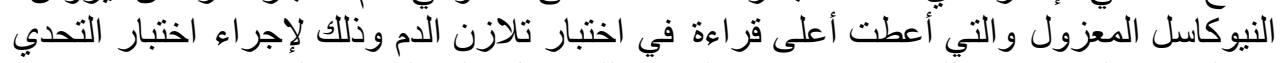

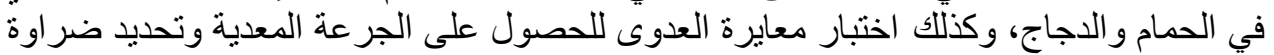

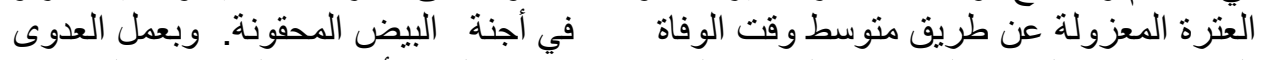

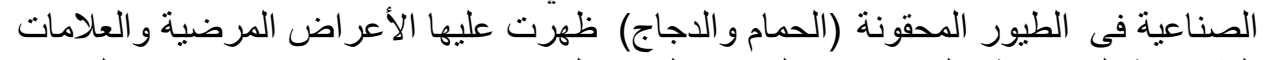

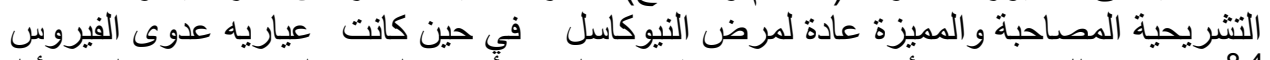

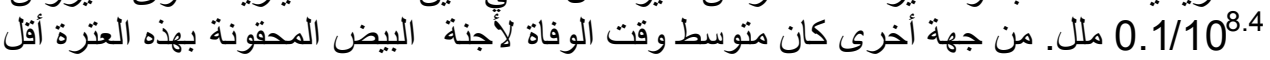

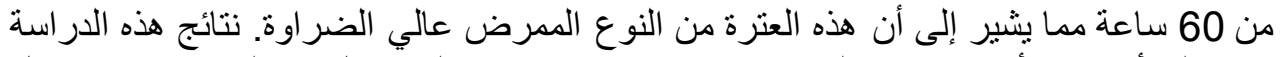

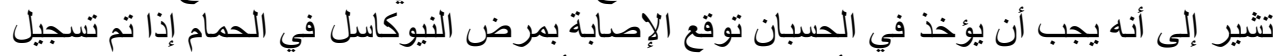

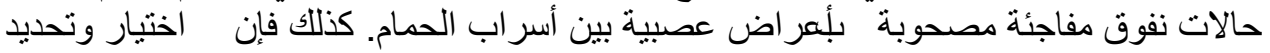

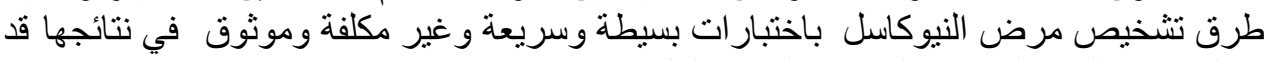
تختلف وفقا للبنية التحتية و المعدات المتاحة لكل مختبر. SUMMARY 
A total of 15 pigeon samples were randomly collected during summer 2007; from Moshtoher village, kalubia province, Egypt; from an outbreak in pigeon loft suffering from nervous manifestations. polling of trachea, lungs, liver, spleen, heart, brain and kidneys for each bird were done. Newcastle disease virus (NDV) was detected and confirmed in $3 / 15,5 / 15$, $3 / 15,3 / 3$ and $12 / 15$ of this field samples, as well as; $6 / 15,9 / 15,15 / 15$, $15 / 15$ and $15 / 15$ of its corresponding inoculated allantoic fluid (AF) by electron, immuno electron microscopy, hemagglutination (HA), hemagglutination inhibition (HI) and reverse transcription polymerase chain reaction (RT-PCR) assays respectively. One isolate (highest HA titer) was tested for: challenge in pigeons and chickens, infectivity titration to obtain infective dose $50 \%$ ( $\mathrm{ID}_{50}$ ), and pathotyping by mean death time (MDT) in embryonated chicken eggs. The infected birds developed noticeable Newcastle disease (ND) clinical and necropsy signs, $10^{8.4}$ EID $_{50}$ $/ 0.1 \mathrm{ml}$ was achieved, while; the MDT value obtained was $<60$ hours. The NDV was found to be velogenic; highly virulent isolate. The results of the present study indicated that ND should be suspected in pigeons whenever sudden deaths, and nervous signs were recorded. Simple, fast, cheap, reliable and effective methods for diagnosis of NDV from infective materials are varied according to the infrastructure and viable equipments of the lab.

Key words: Hemagglutination, Immuno electron, Newcastle disease, Pigeon, RT-CR..

\section{INTRODUCTION}

Newcastle disease (ND) is caused by specified viruses of the avian paramyxovirus type I (APMV-I) serotype of the genus Avulavirus belonging to the subfamily Paramyxovirinae, family Paramyxoviridae. The paramyxoviruses isolated from avian species have been classified by serological testing into nine serotypes designated APMV-1 to APMV-9; Newcastle disease virus (NDV) has been designated APMV-1 (Alexander, 2003). The virus is enveloped and has a negative-sense, single-stranded RNA genome of approximately $15 \mathrm{~kb}$ (De Leeuw and Peeters, 1999) which codes for six proteins, including an RNA-directed RNA polymerase (L), hemagglutinin-neuraminidase protein $(\mathrm{HN})$, fusion protein $(\mathrm{F})$, matrix protein $(\mathrm{M})$, phosphoprotein $(\mathrm{P})$, and nucleoprotein $(\mathrm{N})$ (Lamb and Kolakofsky, 1996). Currently, there are multiple NDV lineages circulating 
worldwide that are genetically highly diverse (Seal et al., 1998; Crespo et al., 1999; Capua et al., 2002; Aldous et al., 2003; Ujvari et al., 2003). Chickens are highly susceptible to virulent APMV-1, while ducks and geese may be infected but show few or no clinical signs (Alexander, 1997). Members of the Columbidae family may be infected with APMV-1 adapted to those particular avian species, designated pigeon paramyxovirus 1 (PPMV-1), and are also susceptible to infection by NDV strains that produce clinical disease in chickens (Alexander et al., 1985; Kommers et al., 2002; Ujvari et al., 2003; Zanetti et al., 2003). Virulent forms of NDV are of major concern for poultry producers around the world and the rapid diagnosis of an outbreak is crucial to any control program of the disease (Kim et al., 2006).

The objective of the present study was to detect, isolate and pathotyping the suspected avian paramyxovirus type 1 (NDVs) from pigeons showed nervous manifestation, as well as to compare and to evaluate a simple, fast, cheap, reliable and effective methods for diagnosis of NDV from infective materials.

\section{MATERIALS and METHODS}

\section{Sample collection and preparation:}

During summer 2007; specimens from Moshtoher village, kalubia province, Egypt; were collected from 15 pigeons of varying ages during an outbreak in pigeon loft suffering from nervous manifestations, sudden deaths, severe depression and loss of appetite. Samples from each bird included trachea, lungs, liver, spleen, heart, brain; kidneys were aseptically collected, pooled in batches, grinded and homogenized in PBS $(1 \mathrm{gm} / 10$ $\mathrm{ml}$ ) and centrifuged according to Burleson et al. (1997). Supernatants of the organs used for viral isolation after 1 hour incubation at room temperature with antibiotics mixture (200 IU of penicillin, $200 \mathrm{mg}$ of streptomycin, $100 \mathrm{mg}$ of gentamicin, and $50 \mathrm{IU}$ of nystatin per $\mathrm{ml}$ ), were harvested. All the supernatants were stored at $-65^{\circ} \mathrm{C}$ until used.

\section{Bacteriological and fungal examination:}

Trails for isolation and identification of pathogenic bacteria or fungus from direct prepared sample (DPS) and harvested allantoic fluid (AF) were done.

\section{Virus isolation and titration:}


According to Burleson et al. (1997), for virus isolation and propagation; $0.1 \mathrm{ml}$ aliquot of the DPS suspension was inoculated into the allantoic cavity of 9-11 day old embryonated chicken eggs (ECE); three eggs were inoculated per sample. The eggs were incubated at $37{ }^{\circ} \mathrm{C}$ for 3-5 days and the $\mathrm{AF}$ were harvested, clarified by centrifugation at $5000 \mathrm{rpm}$ for $10 \mathrm{~min}$. and stored at $-20{ }^{\circ} \mathrm{C}$. For virus titration; dilution from $10^{-1}$ to $10^{-10}$ was inoculated into allantoic cavity using five egg per each dilution then egg infective dose $50 \%\left(\mathrm{EID}_{50}\right)$ was calculated according to formula of Reed and Mench (1938).

\section{Virus inoculation and challenge:}

At eight and seven week of ages, 3 pigeons and 3 chickens correspondingly were used for the study; the birds contain less than $2^{2} \mathrm{ND}$ antibody titers. $1 \mathrm{ml} / \mathrm{bird}$ of the virus containing $100 \mathrm{EID}_{50} / 0.1$ were injected intramuscularly. The birds in the infected and control groups were observed daily for clinical signs of ND. The dead birds were necropsied and examined for gross lesions. Samples from each bird were collected and prepared as mentioned.

\section{Electron microscopy (EM) and immuno electron microscopy (IEM) assays:}

For EM; prepared viral samples according to Veits et al. (2006); were adsorbed to formvar-coated copper grids for $7 \mathrm{~min}$. The grids were washed four times with PBS containing $0.5 \%$ bovine serum albumin (PBSA), continuously; for IEM the grids were incubated for 45 min with a NDV- specific hyper-immune serum, kindly supplied by Newcastle disease department, Veterinary Serum and Vaccine Research Institute (VSVRI), Cairo, Egypt. After several washes with PBSA, both grids were counterstained with $3 \%$ phosphotungistic acid (pH 7.2), and examined with an electron microscope (JEOLES, Japan), in electron microscopic unite, Faculty of Science, Alexandria University.

\section{Hemagglutination (HA) and hemagglutination inhibition (HI) assays:}

The HA and HI tests were done by microtiter methods using $0.5 \%$ chicken erythrocyte suspension in PBS according to the OIE protocols for NDV (Anonymous, 2006) for the DPS and harvested AF. The presence of NDV was confirmed by HI assay with NDV-specific hyper-immune serum (VSVRI).

\section{RNA extraction:}


RNA was extracted directly from DPS, infected AF whether showing hemagglutinating activity or not, and control APMV-1 strain (kindly supplied by Newcastle disease department, VSVRI); with QIAamp ${ }^{\circledR}$ Viral RNA Mini Kit (Qiagen, Germany) according to the manufacture procedures.

\section{Reverse transcription (RT) and polymerase chain reaction (RT-PCR) assays:}

Synthesis of complementary DNA (cDNA) was performed using transcriptor first strand cDNA synthesis kit (Roche®, cat no. 04374012 001) following the manufacture procedures. Reverse transcription was carried out on dry block at $55{ }^{\circ} \mathrm{C}$ for 30 minutes followed by $85{ }^{\circ} \mathrm{C}$ for 5 minutes. RT products were cooled on ice and stored at $-20 \mathrm{C}^{\mathrm{o}}$ until use. The samples RT were tested with primer previously adopted for APMV-1 (Wise et al., 2004), matrix - M+4100 - 5'- AGT GATGTG CTC GGA CCT TC -3 ' and M-4220 - 5' - CCT GAG GAG AGG CAT TTG CTA -3 ' (TIB-MOL BIOL syntheselabor GumbHm Berlin, Germany), the amplicon size is $121 \mathrm{bp}$.

PCR was performed with a slight modification in the reaction mix concentration and amplification procedures; using the PCR Thermo-Cycler Instrument (Techne, TC-312, UK) and $200 \mu$ capacity thin wall PCR tube. Each reaction had a volume of $50 \mathrm{ul}$ including $25 \mathrm{ul}$ of 1x PCR Master Mix [Roche, Germany, Cat. No. 11636103001 ]; containing 25 U Taq DNA polymerase in Tris- $\mathrm{HCl}(20 \mathrm{mM}), \mathrm{KCl}(100 \mathrm{mM}), \mathrm{Mgcl}_{2}(3 \mathrm{mM})$ and dNTP mix (dATP, dCTP, dGTP, dNTP each $0.4 \mathrm{mM}), 1 \mu \mathrm{l}$ each primer $(10$ $\mathrm{p}$ moles of each primer), $8 \mathrm{ul} \mathrm{cDNA}$ and $15 \mu \mathrm{l}$ of PCR grade water. The cycling conditions for APMV-1 consisted of 40 cycles of 10 s denaturation, at $94{ }^{\circ} \mathrm{C}, 30$ s of annealing at $56{ }^{\circ} \mathrm{C}$, and extension of $72{ }^{\circ} \mathrm{C}$ for $10 \mathrm{~s}$. Positive control for APMV- 1 consists of Lasota vaccine (VSVRI). PCR products were separated in $1.5 \%$ agarose gel in $1 \mathrm{x}$ TAE buffer stained with ethidium bromide, compared with molecular mass marker and visualized by ultraviolet (UV) transillumination.

\section{Viral pathotyping:}

One isolate of NDV (highest HA titer) was inspected for pathotyping using mean death time in eggs (MDT) according to Hanson, (1980).

\section{RESULTS}


The clinical signs recorded in examined pigeons and inoculated birds exhibited a state of prostration and depression, with ruffled feathers and greenish white diarrhea; as well neurological signs were recorded (Fig. 1); where the head turned to one side; a condition known as torticollis; and paralysis of the legs and wings were seen.

At necropsy, the examined and infected pigeons had evidence of dehydration, weight loss, congestion of muscles of the breast, thighs and legs. The heart, spleen, and liver were friable and congested. Hemorrhagic enteritis was also observed while the proventriculus of infected pigeons revealed the proventriculitis; the pathgnomic lesions of NDV infection (Fig. 2). Neither significant pathogenic bacteria nor fungi were isolated. Only samples in which the presence of NDV antigens could be confirmed were considered positive. The findings are summarized in (Tab. 1).

Of the 15 DPS, three were found positive (20\%), and of the 15 collected AF, six (40\%) were found positive revealing characteristic morphology for NDV by direct electron microscopy (Fig. 3), while aggregated and clumping of NDV antigens with added known serum were monitored by immuno electron microscopy assay (Fig. 4), where 5 of 15 (34\%) and 9 of 15 (60\%), for DPS and AF were positive, respectively.

HA activity was recorded with 3 DPS and all examined 15 AF harvests on first passage, which gave 512-1024 virus titer. Complete, clear and consistent HA reactions were observed within 5-20 minutes of incubation at $37{ }^{\circ} \mathrm{C}$ or $4{ }^{\circ} \mathrm{C}$ and remained stable for more than 1 hour at room temperature followed by elution. All plates HA positive samples, were found to be positive for NDV heamagglutinine antigen presentations by HI assay.

NDV could be detected by RT-PCR (Fig. 5) in 12 of 15 (80\%) DPS while all 15 AF collected from embryonated chicken eggs that were inoculated in this work were positive (100\%).

Infectivity titration of $10^{8.4} \mathrm{EID}_{50} / 0.1 \mathrm{ml}$ was obtained for the examined virus, while MDT was less than 60 hours indicating highly virulent NDV isolate pathotyping.

NDV were re-isolated in ECE, detected and identified from all inoculated pigeon and chickens by HA, HI and PCR used in this study.

Table 1: Comparison of different diagnostic tests of NDV from infective materials. 


\begin{tabular}{|c|c|c|c|c|c|c|c|c|c|c|}
\hline TEST & \multicolumn{2}{|c|}{ EM $^{1}$} & \multicolumn{2}{|c|}{ IEM $^{2}$} & \multicolumn{2}{c|}{$\mathrm{HA}^{3}$} & \multicolumn{2}{c|}{$\mathrm{HI}^{4}$} & \multicolumn{2}{c|}{ PCR $^{5}$} \\
\hline Sample & DPS $^{*}$ & $\mathrm{AF}^{* *}$ & DPS & AF & DPS & AF & DPS & AF & DPS & AF \\
\hline$+\mathrm{ve}$ & $3 / 15$ & $6 / 15$ & $5 / 15$ & $9 / 15$ & $3 / 15$ & $15 / 15$ & $3 / 3$ & $15 / 15$ & $12 / 15$ & $15 / 15$ \\
\hline$\%$ & $20 \%$ & $40 \%$ & $34 \%$ & $60 \%$ & $20 \%$ & $100 \%$ & $100 \%$ & $100 \%$ & $80 \%$ & $100 \%$ \\
\hline
\end{tabular}

*; Direct prepared sample.

1; Electron microscop.

3; Hemagglutination.

5; Reverse transcription polymerase chaine reaction.
**; Allantoic floid.

2; Immuno electron microscop.

4; Hemagglutination inhebtion.

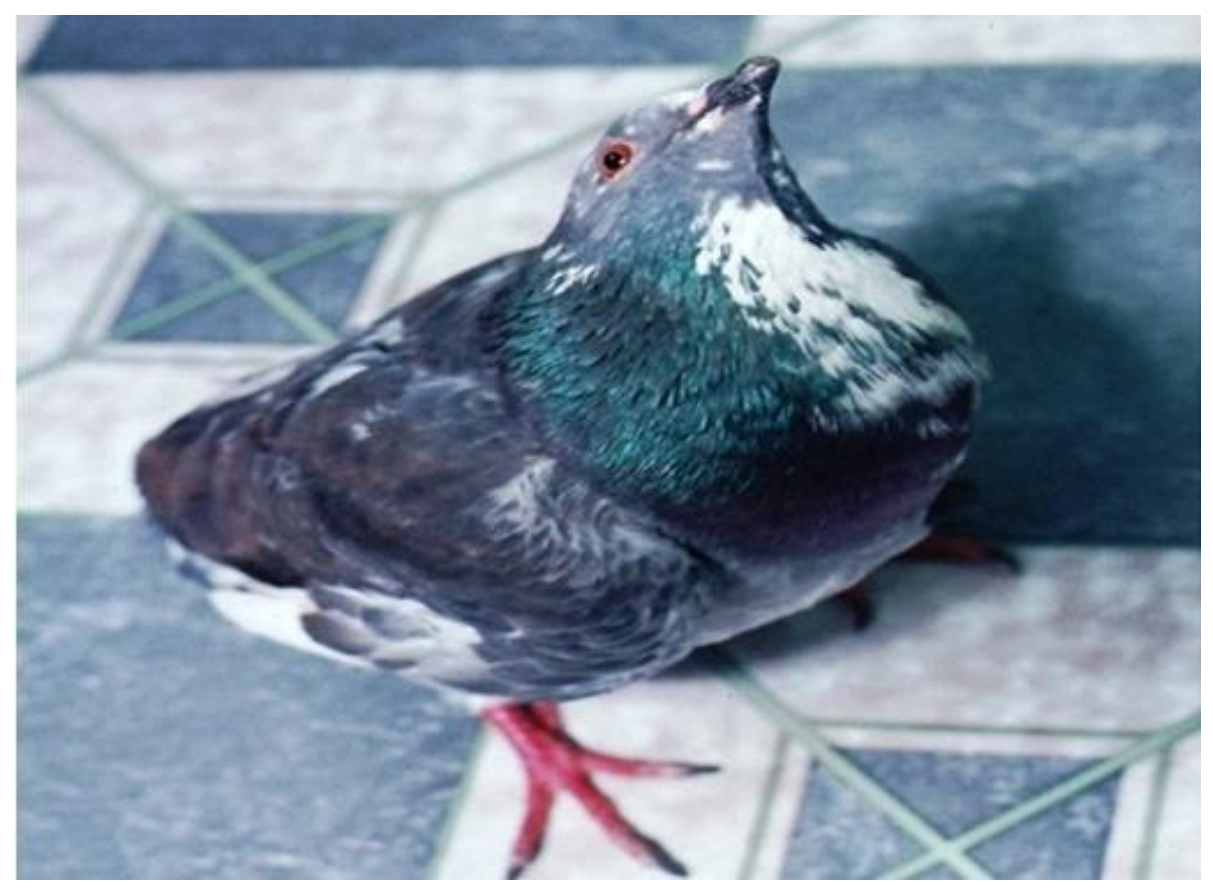

Fig.1: Clinical field case of pigeons suffering from nervous manifestation. 


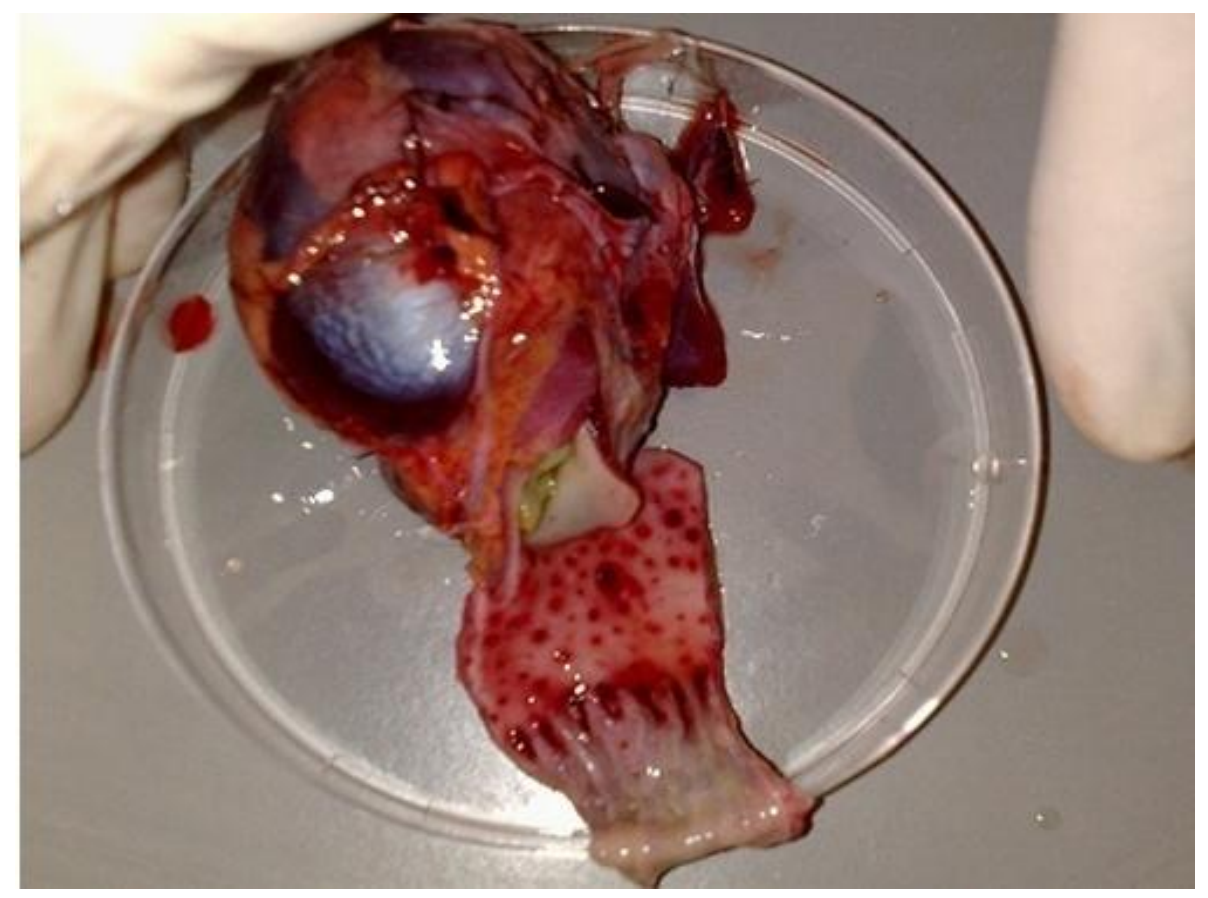

Fig. 2: Hemorrhagic proventreculitis lesion of inoculated NDV.

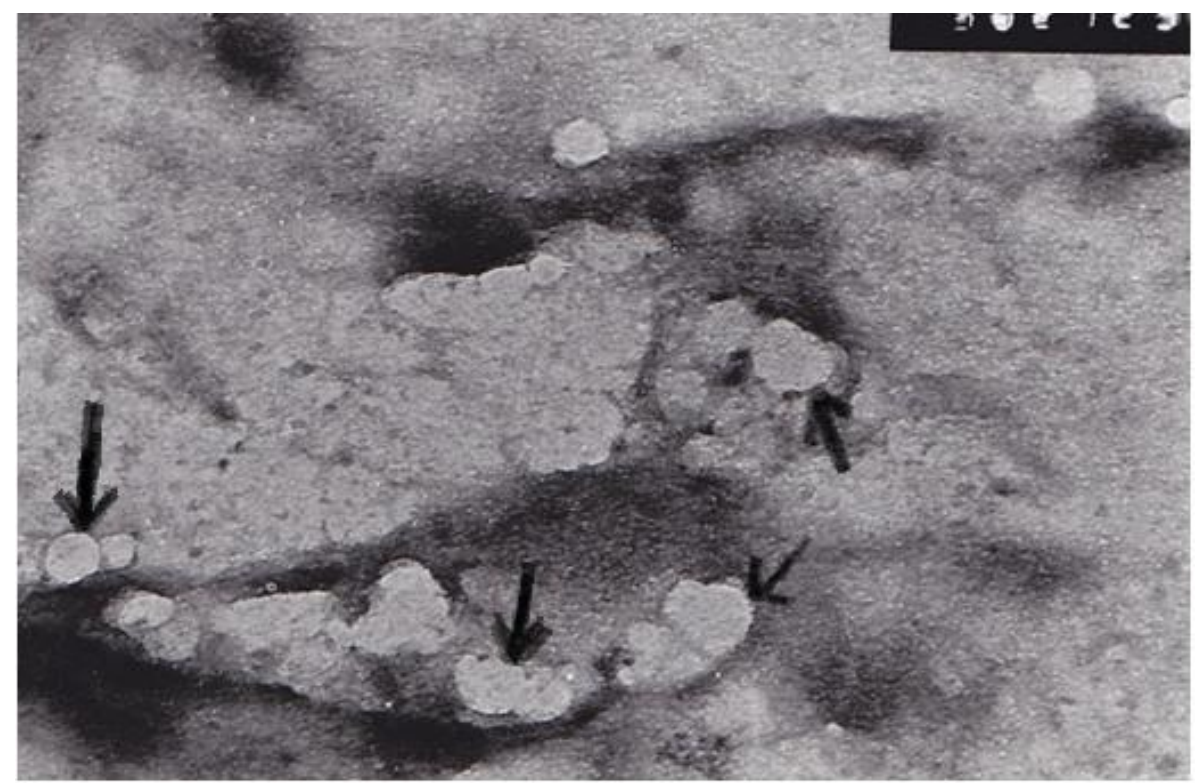

Fig. 3: Characteristic APMV1 (NDVs) appearance by direct electron microscopy. 


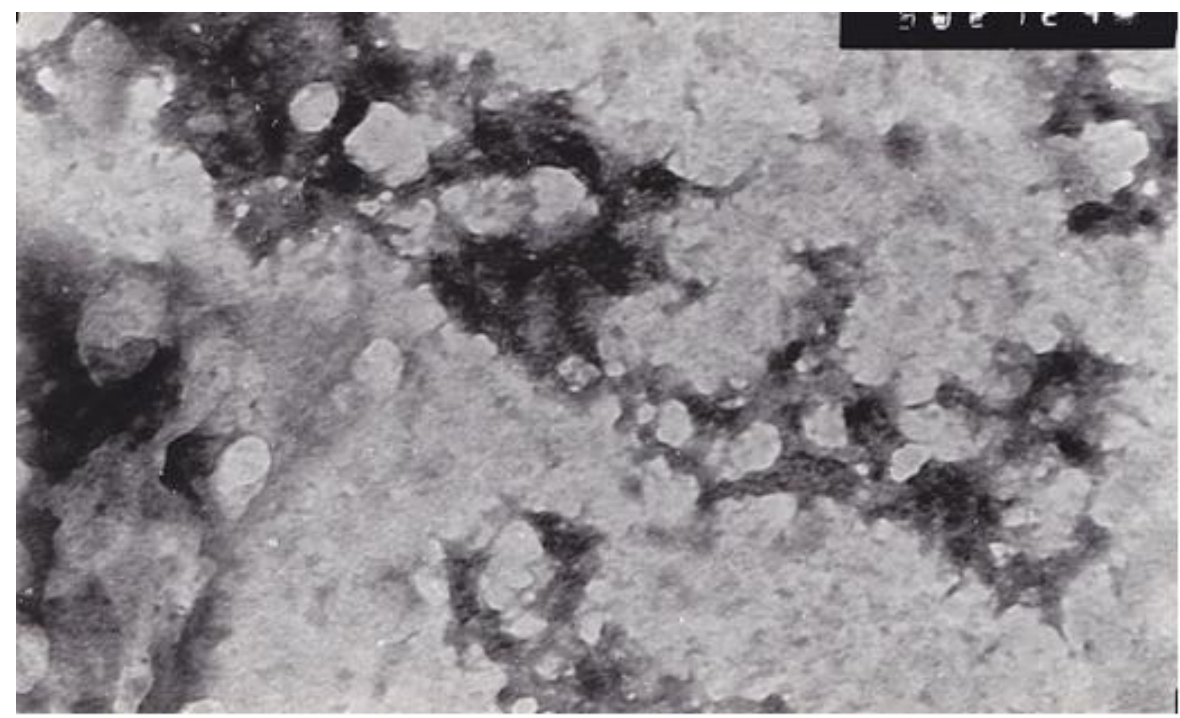

Fig. 4: Immuno electron microscopy of NDV, the virions were binding and clumped by added antisera against NDV.

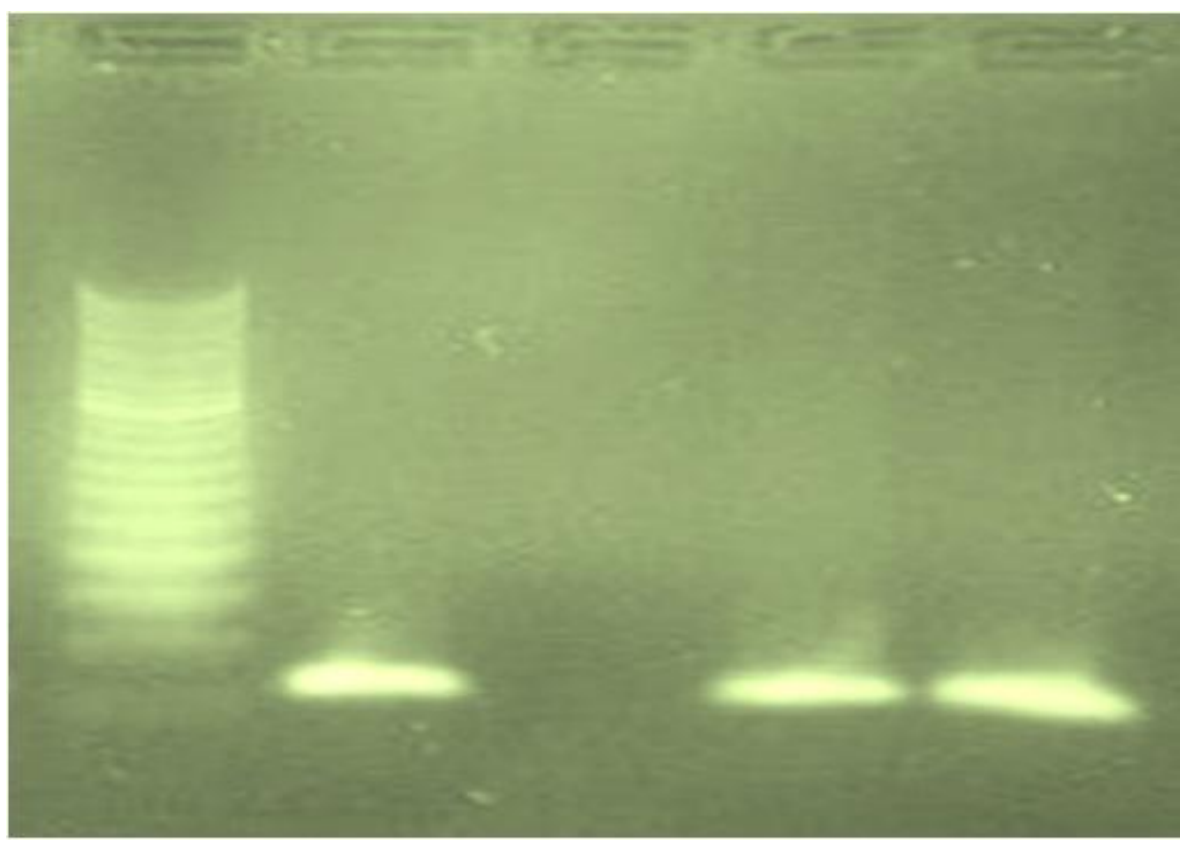

Fig. 5: Agarose gel electrophoresis of $121 \mathrm{bp}$ PCR products of NDV field isolates and reference strain, from left: Lane 1, 2 \& 3: 100 bp DNA Ladder as molecular size marker, + ve \& - ve control. Lane 4 \& 5: + ve examend samples. 


\section{DISCUSSION}

Rapid detection and identification of the NDV is crucial for the effective control of the disease (Kim et al., 2006). Nevertheless, signs and lesions may be considered highly suggestive (Beard and Hanson, 1984). Typical clinical sign and lesions of ND in the examined pigeons and experimental infected pigeons and chickens in this study were similar to those previously observed in chickens (Alexander and Parsons, 1986; Sa'idu et al., 2006) and pigeons (Kapczynski et al., 2006).

A definitive diagnosis of ND requires virus isolation, on ECEs followed by identification of the isolate as PMV-1 (Alexander, 1998) and a determination of the pathotype of the virus isolates (Rojs et al., 2002).

The use of electron and immuno electron microscopy to detect and identify APMV-1 infections in our work has been reported; the immunosera were specifically bound to the antigen determinants located on the virion surface and these results were much easier to interpret; as by IEM the number of virions in native allantoic fluids was increased 50-100 times in comparison with direct EM (Doumanova and Alexandrov, 1997). However to our knowledge, studies reporting the use of those methods to define presence of APMV-1 infection in pigeons are scarce. Nevertheless; duck viruses isolated in the United States in migrating feral ducks were characterized as paramyxovirus strains, because of their morphology in the electron microscope (Webster et al., 1976). Although the cost of this system is slightly higher than that of other systems, the added benefit of a shorter identification time as well as for identification of this infection among other viral or bacterial infections or when NDV could not be recovered by virus isolation, may make this system a viable alternative in some veterinary diagnostic laboratories or as an adjunct to the classical tests used in identification of NDV.

Our data with HA assay revealed the presence of positive hemagglutinating antigens at different temperatures that, were inhibited using known NDV antiserum. The HA and HI assays have the advantages of being easily done with little expensive or extensive equipments and is still widely used throughout the world (Heckert and Eva Nagy, 1999).

RT-PCR for the detection of NDV was first described by Jestin and Jestin, (1991), then applied in different modifications (Aldous and Alexander 2001) e.g. using universal primers to detect all NDVs (Gohm et al., 2000; Creelan et al., 2002; Wise et al., 2004), and pathotype specific primers or nested PCR that enable rapid differentiation of the NDVs 
pathotype (Jestin et al., 1993; Kant et al., 1997; Kho et al., 2000). In our study we have applied RT-PCR method for the detection and identification of NDVs using universal primer in direct prepared samples, allantoic fluids of ECE and then in tissues of experimentally infected chickens and pigeons where specific target amplicon was detected.

PCR is a direct detection of NDV on the basis of genetic database, so it can diagnose very fast and accurate and can amplify only specific gene using the PCR method, and take only $6 \sim 8$ hours for detection in comparison with the standard virus isolation (up to 2 weeks). Therefore, it is a very fast accurate, reliable technique for detection of NDVs. However, this method has limitations especially in remote areas where PCR systems are unreliable or unavailable.

All strains of Newcastle disease virus (NDV) are morphologically and serologically indistinguishable, but differ in their pathotype (virulence) for chickens or eggs (Alexander and Allan, 1973) as measured by standard techniques (Allan et al., 1973). The terms velogenic, mesogenic and lentogenic of NDVs refer to the virulence and expected by MDT in eggs (Hanson and Brandly, 1955; Rojs et al., 2002) while viscerotropic or neurotropic refer to the pathology of the disease produced (Alexander and Allan, 1974). In the current study, a single isolate of this pigeon NDV (highest HA titer) was found to be velogenic; highly virulent; where the obtained MDT was $<60$ hours, while the pathology of the disease obtained was neurotropic in nature.

The role of NDV infection in pigeons and other wild or migratory birds is still not fully understood and measures to control the spread of NDV are very difficult to implement in wild or loft bird populations. Therefore, understanding the ecology of NDV in these populations is necessary to minimize the impact of future ND outbreaks.

This study represents the first step to explore the potential for spread and diagnosis of NDV in the pigeons by using variable identification systems appear suitable for use in the veterinary diagnostic laboratory settings as varied according to the infrastructure and viable equipments.

\section{AKNOWLEDGMENT}

The authors are grateful for Dr. Kamal Zidan (New Cairo poultry Company, Egypt) and Dr. khaled Dokhan (Pathology Department, Animal Reproduction Research Institute, Cairo) for collaboration in this work. 


\section{REFERENCES}

Aldous, E.W. and Alexander, D.J. (2001): Detection and differentiation of Newcastle disease virus (avian paramyxovirus type 1). Avian Pathol. 30: 117-128.

Aldous, E.W.; Mynn, J.K.; Banks, J. and Alexander, D.J. (2003): A molecular epidemiological study of avian paramyxovirus type 1 (Newcastle disease virus) isolates by phylogenetic analysis of a partial nucleotide sequence of the fusion protein gene. Avian Pathol. 32: 239-256.

Alexander, D.J. (1997): Newcastle disease and other avian Paramyxoviridae infections, p. 541-570. In B.W. Calnek, H.J. Barnes, C.W. Beard, L.R. McDougald, and Y.M. Saif (ed.), Diseases of poultry, 10th ed. Iowa State University Press, Ames, Iowa.

Alexander, D.J. (1998): Newcastle disease virus and other avian paramyxoviruses, p. 156-168. In D. E. Swayne, J. R. Glisson, M. W. Jackwood, J. E. Pearson, and W. M. Reed (ed.), A laboratory manual for the isolation and identification of avian pathogens, 4th ed. American Association of Avian Pathologists, Kennett Square, $\mathrm{Pa}$.

Alexander, D.J. (2003): Newcastle disease, other avian Paramyxoviruses and pneumovirus infections: Newcastle disease. In: Diseases of Poultry, Saif Y.M., ed. Iowa State University Press, USA, 64-87.

Alexander, D.J. and Allan, W.H. (1973): Newcastle disease. The nature of the virus strains. Bulletin office International des Epizooties. 79: $15-26$.

Alexander, D.J. and Allan, W.H. (1974): Newcastle disease virus pathotypes. Avian Pathol. 3: (4) 269-278.

Alexander, D.J. and Parsons, G. (1986): Pathogenicity for chickens of avian paramyxovirus type 1 isolates obtained from pigeons in Great Britain during 1983-1985. Avian Pathol. 15: 487-493.

Alexander, D.J.; Russell, P.H.; Parsons, G.; Abu Elzein, E.M.E.; Ballouh, A.; Cernik, K.; Engstrom, B.; Fevereiro, M.; Fevereiro, H.J.A.; Fleury, H.J.A.; Guittet, M.; Kaleta, E.F.; Kihm, U.; Kosters, J.; Lomniczi, B.; Meister, J.; Meulemans, G.; Nerome, K.; Petek, M.; Pokomunski, S.; Polten, B.; Prip, M.; Richter, R.; Saghy, E.; Samberg, Y.; Spanoghe, L. and Tumova, B. (1985): Antigenic and biological characterization of avian paramyxovirus type 1 isolates 
from pigeons-an international collaborative study. Avian Pathol. 14: 365-375.

Allan, W.H.; Lancaster, J.E. and Töth, B. (1973): The production and use of Newcastle disease vaccines. P53 Food and Agriculture Organization of the United Nations: Rome.

Anonymous (2006): Chapter 2.1.15. Newcastle disease, pp. 270-282. In OIE manual of diagnostic tests and vaccines for terrestrial animals. OIE World Organization for Animal Health, Paris, France.

Beard, C.W. and Hanson, R.P. (1984): Newcastle disease. In: Diseases of Poultry 8th Edit., M.S. Hofstad, H.J. Barnes, B.W. Calnek, W.M. Reid, and H.W. Yoder Eds, Iowa State University Press, Ames, pp. 452-70.

Burleson, F.G.; Chambers, T.M. and Wiedbrank, D.L. (1997): Virology: A laboratory manual. Academic press, INC, Harcourt Brace Jovanovich, publisher.

Capua, I.; Pozza, M.D.; Mutinelli, F.; Marangon, C. and Terrigino, S. (2002): Newcastle disease outbreaks in Italy during 2000. Vet. Rec. 150: 565-568.

Creelan, J.L.; Graham, D.A. and McCullough, S.J. (2002): Detection and differentiation of pathogenicity of avian paramyxovirus serotype 1 from field cases using one-step reverse transcriptase-polymerase chain reaction. Avian Pathol. 31: 493-499.

Crespo, R..; Shivaprasad, H.L.; Woolcock, P.R.; Chin, R..P.; DavidsonYork, D. and Tarbell, R..(1999): Exotic Newcastle disease in a game chicken flock. Avian Dis. 43: 349-355.

De Leeuw, O. and Peeters, B. (1999): Complete nucleotide sequence of Newcastle disease virus: evidence for the existence of a new genus within the subfamily Paramyxovirinae. J. Gen. Virol. 80: 131-136.

Doumanova, L. and Alexandrov, M. (1997): Detection and identification of the Newcastle disease virus infection by electron and immune electron microscopy. Acta Virol. 41: (2) 111-4.

Gohm, D.S.; Thur, B. and Hofmann, M.A. (2000): Detection of Newcastle diseases virus in organs and feces of experimentally infected chickens using RT-PCR. Avian Pathol. 29: 143-152.

Hanson, R.P. (1980): Newcastle disease. In: Isolation and Identification of Avian Pathogens, Hitchner S.B., Purchase HG. \& Williams J. E., eds. AAAP, College Station, Texas, USA, 63-66. 
Hanson, R.P. and Brandly, C.A. (1955): Identification of vaccine strains of Newcastle disease virus. Science. 122: 156-157.

Heckert, R.A. and Eva Nagy (1999): Evaluation of the hemagglutinationinhibition assay using a baculovirus-expressed hemagglutininneuraminidase protein for detection of Newcastle disease virus antibodies. J. Vet. Diagn. Invest. 11: 99-102.

Jestin, V. and Jestin, A. (1991): Detection of Newcastle disease virus RNA in infected allantoic fluid by in vitro enzymatic amplification (PCR). Arch. Virol. 118: 151-161.

Jestin, V.; Cherbonnel, M. and Arnauld, C. (1993): Direct identification and characterization of A-PMV-1 from suspicious organs by nested PCR and automated sequencing. Proceedings of the Joint First Annual Meetings of the National Newcastle Disease and Avian Influenza Laboratories of the European Communities, Brussels, pp. 89-97.

Kant, A.; Koch, G.; Van Roozelaar, D.; Balk, F. and Ter Huurne, A. (1997): Differentiation of virulent and non-virulent strains of Newcastle disease virus within 24 hours by polymerase chain reaction. Avian Pathol. 26: 837-849.

Kapczynski, D.R.; Wise, M.G. and King, D.J. (2006): Susceptibility and Protection of Native and Vaccinated Racing Pigeons (Columbia livia) Against Exotic Newcastle Disease Virus from the California 2002-2003 Outbreak. Avian Dis. 50: 336-341.

Kho, C.L.; Mohd Azmi, M.L.; Arshad, S.S. and Yusoff, K. (2000): Performance of an RT-nested PCR ELISA for detection of Newcastle disease virus. J. Virol. Methods. 86: 71-83.

Kim, L.M.; King, D.J.; Curry, P.E.; Suarez, D.L.; Swayne, D.E.; Stallknecht, D.E.; Slemons, R.D.; Pedersen, J.C.; Senne, D.A.; Winker, K. and Afonso, C.L. (2006): Phylogenetic diversity among low-virulence Newcastle disease viruses from waterfowl and shorebirds and comparison of genotype distributions to those of poultry-origin isolates. J. Virol. 81: 12641-53.

Kommers, G.D.; King, D.J.; Seal, B.S.; Carmichael, K.P. and Brown, C.C. (2002): Pathogenesis of six pigeon-origin isolates of Newcastle disease virus for domestic chickens. Vet. Pathol. 39: 353-362.

Lamb, R.A. and Kolakofsky, D. (1996): Paramyxoviridae: The viruses and their replication, p. 1177-1204. In B. N. Fields, D. M. Knipe, and P. M. e. a. Howley (ed.), Fields Virology, $3^{\text {rd }}$ ed. Lippincott, Philadelphia, $\mathrm{Pa}$. 
Reed, L.J. and Muench, H. (1938): Simple method of estimating fifty percent end point. Amer. J. Hyg. 27: 493-497.

Rojs, O.Z.; Krape, U.; Grom, J. and Maganja, D.B. (2002): Molecular detection and pathotyping of paramyxovirus type 1 isolates (Newcastle disease virus). Slov. Vet. Res. 39: (1) 39-45.

Sa'idu, L.; Abdu, P.A.; Tekdek, L.B.; Umoh, J.U.; Usman, M. and Oladele, S.B. (2006): Newcastle disease in Nigeria. Nig. Vet. J. 27: 23-32.

Seal, B.S.; King, D.J.; Locke, D.P.; Senne, D.A. and Jackwood, M.W. (1998): Phylogenetic relationships among highly virulent Newcastle disease virus isolates obtained from exotic birds and poultry from 1989 to 1996. J. Clin. Microbiol. 36: 1141-1145.

Ujvari, D.; Wehmann, E.; Kaleta, E.F.; Werner, O.; Savic, V.; Nagy, E.; Czifra, G. and Lomniczi, B. (2003): Phylogenetic analysis reveals extensive evolution of avian paramyxovirus type 1 strains of pigeons (Columba livia) and suggests multiple species transmission. Virus Res. 96: 63-73.

Veits, J.; Wiesner, D.; Fuchs, W.; Hoffmann, B.; Granzow, H.; Starick, E.; Mundt, E.; Schirrmeier, H.; Mebatsion, T.; Mettenleiter, T.C. and Angela Romer-Oberdorfer (2006): Newcastle disease virus expressing H5 hemagglutinin gene protects chickens against Newcastle disease and avian influenza. Microbiol. 103: (21) 8197-8202.

Webster, R.G.; Morita, M.; Pridgen, C. and Tumova, B. (1976): Ortho and paramyxoviruses from migrating feral ducks: Characterization of a new group of influenza A viruses. J. General Virol. 32: 217-225.

Wise, M.G.; Suarez, D.L.; Seal, B.S.; Pedersen, J.C.; Senne, D.A.; King, D.J.; Kapczynski, D.R. and Spackman, E. (2004): Development of a Real-Time Reverse-Transcription PCR for Detection of Newcastle Disease Virus RNA in Clinical Samples. J. Clin. Microbiol. 42: 329-338.

Zanetti, F.; Rodriguez, M.; King, D.J.; Capua, L.; Carrillo, E.; Seal, B.S. and Berinstein, A. (2003): Matrix protein gene sequence analysis of avian paramyxovirus 1 isolates obtained from pigeons. Virus Genes 26: 199-06. 